\title{
ÓVULOS*
}

\section{Heddy Navarro}

Yo

la dictadora la esclava

la demócrata

la monarca la socialista la exótica

de Salgari la mapuche heroica

La janequeo

la Inés de Suárez la Tania de Bolivia

La miss mundo del año entrante

La secretaria

la maniquí de la Botique la Jenny de

Carlos Marx

La Evita de Buenos Aires

La Matahari

la Krupskaia

de Lenin

la Amanda de la fábrica

la Rosa de la cocina

la Juana lavandera

la Isidora de Duncan la ñusta tirana

la señora de los milagros

la difunta Correa

que dio de mamar a su hijo

después de muerta

la Quintrala de los ríos

la fiura de Chiloé

la Juana la Alfonsina la Gabriela

la progenitora de los Incas

la machi del Nguillatún

la Meica

Yo la parturienta

seguiré pariendo hombres

a pesar de la bomba de neutrones

y las verdades absolutas

* El presente texto se conserva íntegro, atendiendo a la gramática y ortografía del original. Véase: Navarro Harris, Heddy, Óvulos, http://www.palabrademujer.cl/ovulos/ovulos_6.htm, [consulta: 10 agosto 2011]. (N. del E.) 